\title{
The Christian Experience of Life and the Task of Phenomenology
}

\author{
Heidegger on Saint Paul, Saint Augustine, and Descartes
}

\section{Gert-fan van der Heiden}

Abstract It is well-known that the early Heidegger offers important reflections on the Christian experience of life in his accounts of Saint Paul and Saint Augustine. Yet, what is the systematic meaning of Heidegger's phenomenology of religion? This essay aims to discuss this question by connecting themes from Die Phänomenologie des religiösen Lebens to Heidegger's attempt to provide his own version of phenomenology in Einführung in die phänomenologische Forschung. Heidegger's position with respect to Husserl's phenomenology becomes clearer, I argue, when his problematization of the onto-theological structures he discerns at the heart of the philosophers he discusses, such as Descartes and Augustine, is taken into account and when it is shown how the phenomenology of religion exceeds the boundaries of a phenomenology that studies consciousness alone. In fact, the explication of the (purified) Christian experience of life and the conception of God at stake in this experience allows Heidegger to articulate a form of phenomenology purified from onto-theological tendencies.

Keywords Christian experience of life; God; Heidegger, Martin; onto-theology; phenomenology of religion

\footnotetext{
2 Gert-Jan van der Heiden, The Christian Experience of Life and the Task of Phenomenology. Heidegger on Saint Paul, Saint Augustine, and Descartes, Radboud University, Faculty of Philosophy, Theology, and Religious Studies, Erasmusplein 1, 6525 HT Nijmegen, The Netherlands gert-jan.vanderheiden@ru.nl (D) 0000-0001-9493-3220
} 
In 1918, assessing Heidegger's possible contribution to the phenomenological movement, Husserl suggested to him that he concentrate on the phenomenology of religion (Kisiel 1993, 75). ${ }^{1}$ Considering Heidegger's background in theology and religion, Husserl's proposal seems only reasonable. The young Heidegger struggles with his own Catholic background, converts to Protestantism, is unsure whether to identify as a theologian or a philosopher, and proclaims the end of philosophy but still has hopes of finding a new way for metaphysics (Dahlstrom 2009, 250-1). Following Husserl's recommendation, Heidegger indeed develops a phenomenology of religion in his lecture series on Saint Paul and Saint Augustine. Yet, Heidegger's reflections on religion are not regional phenomenological exercises exploring the field of religion. Rather, they concern and affect the very course and focus of phenomenology.

To understand what is at stake for Heidegger in his recalibration of phenomenology under the guidance of religious experience, we need to identify which phenomena of religious life are basic for Heidegger's concern and we need to offer an interpretation of their specific significance. The working hypothesis of this essay is that the confrontation with the genuinely religious (Christian) experience in both Saint Paul and Saint Augustine calls for a phenomenology purified from the onto-theological motives that it has borrowed from ancient Greek thought and modern epistemological concerns. Elsewhere, I've examined the notion of onto-theology in Heidegger's work (van der Heiden 2014), also in relation to his reading of Saint Paul (van der Heiden 2018, 87-120). Here, I want to show in more detail how onto-theology is at stake for Heidegger in his early reflections on phenomenology and how the original religious experience of life offers the guidelines for a purification of phenomenology. To limit the scope of my discussion, I first show how, for Heidegger, onto-theological structures are present in basic elements of Descartes' account of subjectivity that influence phenomenology. Second, I argue that his lectures on the apostle and the bishop offer another experience of life and of God that provide Heidegger with the means to recalibrate phenomenology.

\section{The Onto-Theological Structure of Descartes' Meditations}

The question of onto-theology takes on different shapes in Heidegger's work and is applied to different motives and concepts in the history of

1. In a letter to Rudolf Otto from 1919, Husserl notes that Heidegger is "religiously oriented," an "'undogmatic Protestant' and a free Christian," and that "in Heidegger the theoretical-philosophical interest is predominant” (Kisiel 1993, 72-3; Vedder 2006, 19-20; Coyne 2015, 1). 
philosophy. Yet, the basic scene to exemplify what onto-theology is-even though Heidegger does not use the term yet-and how it affects modern thought can be found in his account of the Cartesian roots of Husserl's phenomenology. Heidegger's critical discussion of Husserl's phenomenology in Einführung in die phänomenologische Forschung is centered on the question of why consciousness is the privileged theme of phenomenology. Heidegger's comments mainly pertain to Husserl's Philosophie als strenge Wissenschaft (1910), which is published after the Logische Untersuchungen but before the Ideen. Hence, one may question the limitations of this critique and wonder whether and to what extent they apply to Husserl's later works. Nevertheless, these lectures clearly argue why Heidegger thinks it is necessary to revise phenomenology.

For Heidegger, Husserl's phenomenology remains too much indebted to a specific conception of knowledge as (rigorous) science. This conception goes back to Descartes' conception of science, which lays the philosophical foundation for the modern sciences. Heidegger argues that this conception of knowledge is not neutral, but is rather motivated by a care about knowledge. This care is marked by three characteristic possibilities (Heidegger 1994, 126-9; 2005, 91-3): it expresses itself in curiosity, Neugier, that is, in the wish to know all beings encountered in the world; as looking for certitude, Sicherheit, that is, for securing this knowledge; and as looking for knowledge that is binding to humans, Verbindlichkeit, and ultimately universally binding, Allverbindlichkeit (Heidegger 1994, 100-3; 2005, 72-5).

This conception of knowledge, Heidegger suggests, is the basic motivation for Husserl's dismissal of Dilthey in Philosophie als strenge Wissenschaft. Dilthey's approach to and emphasis on history can only lead to skepticism and relativism. Hence, it cannot satisfy the basic care about knowledge motivating Husserl's phenomenology. Consequently, Husserl's dismissal of Dilthey is not guided by an original, phenomenological examination of what history means to human existence, but is rather a consequence of the motivating care about universally binding, certain knowledge. In terms of Husserl's own distinction, Dilthey's approach remains on the empirical level of "matter of fact," without reaching the level of "valid sense." Yet, this equation of history with matter of fact is not the result of a rigorous phenomenological investigation of history, but rather the modern form of an old philosophical prejudice: "A rigorous investigation of the matter is disregarded and a completely banal Platonism is resorted to" (Heidegger 1994, 94; 2005, 68).

This latter remark contains Heidegger's concern in a nutshell: the philosophical care about knowledge, either in its ancient philosophical 
form-"Platonism"-or in its modern form, has a tendency to overlook history as well as the impact of history on human thinking and existing. For instance, in this remark, Heidegger points out that a philosophical legacy-in its Husserlian form: the distinction between matter of fact and valid sense-is taken as absolute. Heidegger, however, insists that the task of phenomenology is rather to examine this distinction: what are its metaphysical presuppositions? In the lecture series, Heidegger's movement from Husserl to Descartes follows exactly this line of inquiry. The conception of knowledge as science is itself a prejudice, a historical-philosophical heirloom, stemming from Descartes. The latter's work is not only important because it offers the early modern version of the care about knowledge, but also because it still carries the traces of the ontological and metaphysical presuppositions on which this conception of knowledge is founded. These metaphysical presuppositions are obscured and hidden in the course of the history of philosophy; and the self-evidence of this conception of knowledge is a consequence of this obscurity of its historical foundation. Therefore, a hermeneutic-phenomenological investigation needs to explicate these hidden, sedimented sources of this conception of knowledge and its motivating care. Only along the lines of such an investigation, the self-evident conception of knowledge may again become a question for us. Hence, the hermeneutic-phenomenological investigation aims to dismantle-abbauen-this self-evidence and is, in this sense, a form of destruction-Destruktion-and of criticism-Kritik-of the present conception of knowledge and the self-evidence with which it is brought forward (Heidegger 1994, 117-22; 2005, 85-8).

\subsection{Descartes' Repositioning of Scholastic Ontology: Verum as Certum} In order to demonstrate the metaphysical presuppositions and the formal role of the Cartesian cogito ergo sum, Heidegger turns to Descartes' Meditations and, remarkably, reads them backwards, starting with the third and fourth Meditation and then moving back to the first and the second one. To understand what this backward reading achieves, it might be helpful to recall Jean-Luc Marion's argument that the Meditations actually invoke two different types of metaphysics (Marion 2004, 97-110; Grondin 2012,110-9). The first and the second Meditation develop a metaphysics in which the primordial being is the subject-ego sum-of which the essence is determined as thinking-cogitare-and in which other beings are understood as thoughts-cogitationes. Interestingly, Marion discerns in this first metaphysics an onto-theological structure. Even though the notion of God does not seem to play a significant role yet in these first two Meditations, 
it is clear that being is determined based on the inquiry of one particular being, namely the ego, and that all other beings are understood in terms of the essence of this particular being. Hence, there is a formal kinship with Heidegger's “onto-theology." Nevertheless, I would insist against Marion's characterization that the modern conception of the subject has never given rise to a theology of the subject, at least not in the historical line leading up from Descartes to Husserl. ${ }^{2}$ In fact, this seems an absurd notion if we think of the subject along the lines of Descartes, Kant, and Husserl, who emphasize the finitude of the ego cogito. The "I think" did give rise to a philosophical psychology or anthropology.

However, for Heidegger, the exemplary case of onto-theology is rather found in the third and fourth Meditation, which invoke a second form of metaphysics going back to Medieval thought (1994, 162-94; 2005, 120-47). In this second metaphysics, the sense of being is determined by the highest being, God. The essence of this being consists in causality, understood in terms of making or creating: God is the creator as well as the highest good, summum bonum, and every other being is determined as ens creatum.

Interestingly, Marion's distinction between two types of metaphysics in the Meditations seems to mirror Husserl's judgment on Descartes. Husserl also discerns a fundamental rupture between the first two Meditations and the others. In fact, as Heidegger reminds us, Husserl claims: "If Descartes had remained at the second Meditation, he would have come to phenomenology" (Heidegger 1994, 268; 2005, 206). The great achievement of these first two Meditations is indeed the discovery of the cogito sum as certitude and, in phenomenology, this discovery is taken over uncritically as self-evident point of departure (Heidegger 1994, 267-8; 2005, 205-6).

At this point, it becomes clear in which sense Heidegger rejects the distinction proposed by Marion and Husserl alike and why he reads the Meditations backwards. The backward reading first shows how, for Descartes, only the third and fourth Meditation and their grounding of the human being as an ens creatum in God can establish the criterion of clear and distinct perceptions as a criterion of truth (Heidegger 1994, 134-5; 2005, 97-8). The crucial claim here is that the human being is itself capable of truth because it is created and, therefore, also directed to the creator, who possesses eternal truth. In Descartes' own image, the clear and distinct perception (of the idea of the infinite) is the signature of God himself in the cogito and is therefore a criterion of truth. Consequently, Heidegger

2. The history of absolute idealism might suggest otherwise: to what extent, one might ask for instance, might Hegel's thought on the subject be seen as a form of theology of the subject? 
writes: "To err is to effect a breach in [to be detrimental to: Abbruch-tun] the genuine being of the created human being" $(1994,161 ; 2005,119)$. This conception of the human capacity to know the truth cannot be understood without taking the scholastic conception of truth into account that founds it. In reference to Thomas Aquinas, Heidegger summarizes this conception as follows: "Thus Thomas acquires, in relation to everything that is, a principal concept of truth that ultimately falls back on the relation of the causare and causari [to cause and to be caused] in the sense of making by way of producing, shaping. The "what" conceived [gedacht] and fashioned [created: erschaffene] by such an intellect is the true being [das wahre Sein] in the primordial sense" $(1994,184 ; 2005,139)$. Hence, the human capacity to know the truth is founded in the divine intellect that has conceived, thought, and created all that is: the clear and distinct perception is the particular evidence that the cogito's idea agrees with God's and is, therefore, true. The price to pay for such a conception is rather high, for Heidegger, because it means that, from the outset, the basic experience the cogito expresses in Descartes, namely that I experience myself thinking, is conceived as an object of the divine intellect, because human consciousness also is ens creatum. By extension, the ego cogito is conceived as that which can become an object of human scientific knowledge in (philosophical) psychology or anthropology $(1994,187 ; 2005,141)$.

Descartes repositions the scholastic ontological framework in one important respect. In Thomistic ontology, the human being as a created being has a propensity for the truth; the human intellect is capable of knowing the true; and knowing the true, verum, is nothing less than the good, bonum, to which the human strives naturally. Descartes displaces or repositionsHeidegger writes several times: Umstellung $(1994,226$; 2005, 172)-this scholastic sense by reinterpreting the true, verum, as the certain, certum. The good to which the human strives and for which the human has a propensity is not simply the true, but rather "truth conceived primarily as certainty." This also repositions the perfectio of the human being: not simply a striving and propensity for the true, but rather "a propensity for certainty" (1994, $225 ; 2005,171)$. For Heidegger, modernity is thus grounded on scholastic ontology, but is at the same time a fundamental repositioning of it, because certum concerns a very specific notion of truth, namely the type of truth attained in mathematics: mathematical knowledge is indeed certain and universally binding $(1994,227 ; 2005,173)$. Striving for this type of truth and knowledge becomes the bonum and the perfectio of the modern human. This also marks the modern care about knowledge "as a care about certainty that from the start precludes any possibility of a fundamental uncertainty 
with respect to being" (1994, 226; 2005, 172; my emphasis). This marks the modern predicament of onto-theology: the care that motivates knowledge effaces the possibility of human uncertainty with respect to (their own) being. Here, humans become almost like God since they are capable of certain knowledge. Heidegger adds "What presents itself here is an extreme Pelagianism of theoretical knowing" (1994, 228; 2005, 173). This latter reference is an invitation to consider Heidegger's reading of Pelagius' opponent, Augustine, who is often considered to be a predecessor of Descartes and the original source of some of his arguments, but apparently is read by Heidegger as an opponent of the Cartesian onto-theological heritage.

\subsection{The Primal Experience of the Self: Cogitare Me Cogitare}

Before turning to Heidegger's reading of Augustine, let us consider where the analysis of Descartes leaves us with respect to phenomenology. If one distinguishes two forms of metaphysics in the Meditations as Marion does and uses this distinction to separate scholastic metaphysics from Descartes' epistemological project, as Husserl suggests, one uproots the Cartesian criterion of self-evidence from its ontological framework. This, Heidegger argues, is exactly what happened when phenomenology took over the cogito sum. Phenomenology "demands the absolute self-evidence of this criterion itself," thus abandoning the scholastic ontological groundwork that made it possible in Descartes. Consequently, however, phenomenology's "cogito sum is free-floating" (1994, 268; 2005, 206).

Needless to say, Heidegger does not suggest to return to the onto-theological constitution of scholastic metaphysics. In fact, he rather draws our attention to a specific dimension of the discovery of the cogito that Descartes does not recognize enough, that he tends to pass over because it does not fit with the focus on and care about certainty that guides his enterprise. As long as absolute self-evidence and certainty is the focus of phenomenology, it necessarily misunderstands how the first and second Meditations are intrinsically connected to the third and fourth. However, a discontinuity in the Meditations does exist if one considers more carefully how Descartes conceives of the ego.

At this point, § 44 of Einführung in die phänomenologische Forschung is of the utmost importance. In the project of attaining certainty, the Cartesian method of doubt results in a formal-ontological proposition on the cogito. Such a proposition is both apodictically true and universally binding and can, therefore, be used as the starting point for a project motivated by the care about certain knowledge. Yet, Heidegger wonders what has happened to the subject matter, die Sache, itself about which the proposition states 
something. Should we not say that in addition to the care about knowledge, which overtakes Descartes' analysis, he is at the same time motivated by the phenomenon of thinking? How is this phenomenon actually given and conceived before it is distorted by the onto-theological interpretation that reduces-Nivellierung-it to an object of the divine intellect and about which a formal-ontological statement is formulated (Heidegger 1994, 158; 2005, 117)? There is one important Cartesian indication of how the phenomenon of the cogito is given originally, before its conception as an object. Thinking, cogitare, is always "cogitare me cogitare [to think that I think]": Cogitare is "a peculiar being [Sein] whose manner of being is in how it has itself along with [Wie des Sich-mit-habens]" (1994, 249; 2005, 193). The term "having" denotes here a relation of understanding of the I to-in this case-itself that cannot be conceived in terms of the modern epistemological relation of subject and object, which belongs to the framework of the conception of knowledge as science (see also Heidegger 1995, 91-3; 2010b, 63-5). This is the genuine discovery of the cogito: in thinking, one has oneself; thinking is a form of auto-affection: in thinking, I experience myself thinking. This evident experience opens up phenomenology.

Yet, what does this experience mean? In thinking, I immediately discover myself; yet, this experience is only present in the enactment-Vollzug-of thinking, which is instantaneous or momentaneous. This instantaneous or momentaneous character of the self-having that thinking discloses is termed Jeweiligkeit (Heidegger 1994, 250; 2005, 193). The German jeweilig means "at this particular moment" and is related to the verb weilen, to sojourn: the enactment of thinking is the genuine sojourn of the self. Any attempt to formalize this experience in an apodictically true and universally binding proposition betrays the momentaneous character of this experience. This does not imply that the Cartesian statement is meaningless or nonsense altogether. However, it only makes sense when understood as formal indication: a general statement of which the meaning is only fulfilled in the (momentaneous) enactment of what is stated. The auto-affection of thinking is not universally true because there is no universal self or subject; the self is only experienced as my self in the momentaneous enactment of my thinking. ${ }^{3}$ Any attempt to objectify this experience abstracts from the enactment. Since the enactment is the basic milieu of the self, this abstraction loses and hides the self-experience. Formulated in temporal terms: while I have myself in the momentaneous enactment of my thinking, it remains fundamentally uncertain whether I will have myself or whether

3. Jeweiligkeit is the precursor of Jemeinigkeit in Sein und Zeit (Heidegger 1977, 57). 
I will rather lose myself. The Cartesian care about certain and universally binding knowledge effaces and obscures this basic uncertainty given at the heart of self-experience.

\section{The Religious Experience of Uncertainty, Contingency, AND UNCANNINESS}

In the winter term of 1919-1920, Heidegger replaces an anticipated lecture series on the philosophy of religion-Die philosophischen Grundlagen der mittelalterlichen Mystik (of which the preparatory notes can be found in (1995, 301-37))-with one on Grundprobleme der Phänomenologie (1993a). Nevertheless, this course's "early hours ... abound in examples from the history of Christianity" (Kisiel 1993, 76-7). Heidegger claims that early Christianity is nothing less than a revolution against ancient science, especially that of Aristotle. This revolution concerns the centralizing of the self and the self-world in Christianity. In the course of medieval thought, however, the Christian attention to "the inner experiences" and the development of "a new positioning of life [Lebensstellung] were clamped into the forms of expression from ancient philosophy [Wissenschaften]" (Heidegger 1993a, 61; 2012, 47). From this observation, a specific task imposes itself, namely to regain access to the original discovery of the self and to extricate it from ancient philosophical categories. Interestingly, for Heidegger, this is not only a task for the philosophy of religion, but also and foremost for phenomenology. He writes that the imprisonment of the Christian experience of life in ancient philosophical terms is "a process that, today, still has a deep and confusing effect; one of the innermost tendencies of phenomenology is to get away from that process and to get away from it radically" (1993a, 61; 2012, 47).

This imprisonment is exemplified by the onto-theological structure of the scholastic conceptions of God and the ens creatum. The destruction of this onto-theological structure, for instance in Heidegger's reading of Descartes, is an attempt to extricate "the basic position [Grundstellung] of the genuine primal Christians" (1993a, 61; 2012, 47). Somehow, their experience offers the phenomenological resource to overcome the onto-theological structure of metaphysics. Consequently, the phenomenology of religion is concerned with nothing less than the project of extricating phenomenology from its ancient philosophical ties. ${ }^{4}$

4. Much of the present-day philosophical turn to the letters of Saint Paul can be understood in similar terms as offering a viable philosophical alternative to onto-theology (van der Heiden and Kooten 2017, 329-35; Heiden 2018, 87-120). 
This imprisonment does not only concern medieval scholasticism. It also affects the work of Augustine. Therefore, a Heideggerian reading of Augustine must dismantle its Greek legacy. At the same time, Augustine's orientation to the self profoundly differs from Descartes' (Campbell 2012, 56-7) and the Greek objectifying tendency (Heidegger 1995, 172; 2010b, 124). Descartes' care about certainty is a "care that tranquilizes [Sorge der Beruhigung]" (Heidegger 1994, 225; 2005, 171). To capture the tension of this care with the one motivating Augustine, we might translate Sorge der Beruhigung as "care that sets our heart at rest." For Heidegger, this setting our heart at rest is a flight for the genuine experience of the self (1994, 290; $2005,221)$. These formulations are clearly inspired by Augustine: in Grundprobleme der Phänomenologie Heidegger emphasizes Augustine's inquietum cor nostrum, "restless is our heart," which articulates "the great incessant restlessness of life" (1993a, 62; 2012, 48; translation slightly adapted). (1993a, 62; 2012, 48; translation slightly adapted). The distress of the self that is expressed by this restlessness concerns the continual risk of losing oneself: "The distress of the self [Bekümmerung des Selbst] is a constant care about the lapsing from the origin" (1993b, 173; 2010a, 133; translation slightly adapted) (1993b, 173; 2010a 133; translation slightly adapted). The origin from which the self fears to lapse is the "self in the actual enactment of life experience, the self in the experiencing of itself is the primal reality" (1993b, $173 ; 2010 \mathrm{a}, 132)$. The primal reality of self-experience is that I experience myself experiencing reality. Hence, the realm of self-experience is not the Cartesian secured space of representations or ideas, but rather the place where reality is encountered as reality. How does Heidegger discern the distress or concern of the self-die Bekümmerung des Selbst-in the Christian experience of life?

\subsection{Saint Augustine's Quaestio Mihi Factus Sum}

The available literature considers Heidegger's reading of Augustine either as an early stage in his philosophy of religion (Vedder 2006, 59-66), as a precursor of motives in Sein und Zeit (Dahlstrom 2009), or as a continuous presence in his work (Coyne 2011). The literature affirms that this reading dismantles the Neo-Platonic framework of Augustine's work, present in the reflections on the summum bonum, on the ultimate pleasure of contemplating the eternal highest being in the form of the fruitio Dei and on the place and function of values-or "axiologization"-to deal with the problems of human temptation (Vedder 2006, 61-3; Coyne 2011, 382). At the same time, Heidegger's reading emphasizes Augustine's discovery of the inner dimension of the human that repositions this ancient philosophical 
framework, even though it remains "clamped into the forms of expression from ancient philosophy." In his reading of Book X of Augustine's Confessiones (hereinafter abbreviated as Conf.) Heidegger captures this double orientation of Augustine in terms of a difference between object or objective content and enactment, Vollzug. While Descartes' thought is overtaken by the orientation on the object and discards and distorts the enactment sense of the cogito me cogitare, Augustine's Confessiones offers a different balance between these two orientations. In the latter's reflections, the enactmental-vollzugsmäßig-sense of self-experience can still be traced.

Coyne's $(2015,53-86 ; 2011)$ reading demonstrates convincingly how, for Heidegger, Augustine provides an alternative to Descartes' conception of the cogito. In his account, Coyne $(2011,373)$ emphasizes that "the Augustinian question of the relation of veritas [truth] and vita [life]" allows Heidegger "to make the sense of this [i.e., Descartes'] idea of truth more accessible for ourselves by orienting 'truth' to existence itself" (Heidegger 1994, 120; 2005, 87). While I do not disagree with the importance of this Augustinian question, I would rather emphasize the other Augustinian question to capture "the discovery of the inner man" (Arendt 1978, 2.53, 2.85): quaestio mihi factus sum, "I have become a question to myself." This discovery implies a different conception of God than the onto-theological one, as can be seen from an extended version of the citation: in cuius oculis mihi quaestio factus sum (Conf., X.33.50), "in or before your-that is, God's-eyes I have become a question to myself." Here, the self is not reduced to an object before the eyes of the divine intellect that, in Descartes' repositioning, secures the ego as an object for possible certain knowledge. Rather than offering a firm grasp on what I am and securing the truth of the criterion of self-evidence, to be before the eyes of Augustine's God means to become uncertain about oneself and, thus, to become a question to oneself.

The whole range of Augustine's self-reflections in Book X are devoted to his becoming a question to himself before the eyes of God. Heidegger argues that this process can be understood as the discovery of the self in an enactmental sense. The analyses in Book X leading up to that of memory are of pivotal importance in this respect. Augustine is searching for God. This small sentence, "searching for God," allows for a double orientation, an objective and an enactmental-vollzugsmäßig-one. The first orientation emphasizes God as object. Augustine cannot find God in the outside world and he concludes that God must be somewhere in his memory. Yet, as soon as he turns inward, his reflections are a "back-and-forth of the considerations regarding experience as the means objectively present-at-hand, and as interpretation regarding enactment” (Heidegger 1995, 181; 2010b, 132). 
The objective orientation in the reflections on the inner self occasions the Diltheyan approach to Augustine (Heidegger 1995, 180; 2010b, 131); by contrast, it is the enactmental one that Heidegger aims to bring out.

Searching for or finding something concerns a particular self-involvement; therefore, neither can be reduced to the objective presence of the thing that is searched for or found. Objectively, the thing might have been present before I found it: lying in the same place during my searching and finding, and so finding it does not change anything in this objective presence. However, when I find a particular thing, I was first looking for it. This means that I already have this thing in one way or another when searching for it, although I have it differently than when I have found it. Consequently, how I have this thing cannot be understood in terms of the thing's objective presence. Hence, in the course of his analysis, Augustine shifts emphasis from God as object-that Augustine fails to find in the outside world and is not capable of locating exactly in his memory-to the "searching for God" as a particular way of having God, that is, to a particular self-relation to God in which one also experiences oneself (namely, as searching; (Heidegger 1995, 181; 2010b, 132)). As Heidegger writes: "the enactment of the search itself is something of the self" $(1995,192 ; 2010 \mathrm{~b}, 141)$. The searching for God thus bears witness to a particular self-concern, Bekümmerung. The concern that distresses Augustine is to find God. Bracketing the Greek contemplative dimension, which is always also present in Augustine, this means that Augustine does not have God as the highest being to which he is naturally oriented, but rather has a concern for himself: he is distressed over not having found God. Hence, the role of God is completely different here than in Descartes, for whom the scholastic idea of God as creator founds the repositioning of verum as certum. Descartes' God does not distress the self, but is rather part of the care that sets one's heart at rest: God is the very ground for the certainty of the self and for the modern ideal of certain knowledge. Augustine's God, however, is a source of distress. God necessarily remains so, as is strikingly expressed in Augustine's idea that God is interior intimo meo, "more inward than my innermost" (Conf., III.6.11). This inwardness or depth of myself cannot be given objectively, it is beyond my (inner) grasp and, therefore, life is a continual searching for God. Therefore, one is placed before the strenuous task to maintain searching, continually to enact this searching. Not searching for God means losing oneself.

Augustine's descriptions of the temptations and the troubles, molestia, of life that follow in Book X all serve to show that life is a continual testing, as Heidegger argues. What is tested is nothing less than the self's search for 
God. These analyses imply a deepening of the distress that I described above as the concern to find God. Augustine's analysis does not only manifest a distress over finding God, but more precisely discloses the religious experience of the self as the distress and concern over the question of whether the self is truly searching for God: since the human cannot have God as an object, the human only has God in the enactment of searching for God. The self only truly has itself when it has God in the form of searching for God. This can be clearly traced in Augustine's analysis of the three forms of dispersion or "defluction"-concupiscentia carnis, concupiscentia oculorum, and ambitio seaculi. This analysis aims to show, according to Heidegger, that each of our everyday activities can be enacted in two ways: either in search of God or in forgetfulness of God and, consequently, self-loss. ${ }^{5}$ In each of these dispersions-the delight we take in the beings around us that we hear, see, or smell; the pleasure of objectively knowing things; and the self-appreciation we feel when our fellow humans praise us-human life is marked by a danger of self-loss, that is, of losing ourselves in these delights, pleasures of knowing or received praises. This possibility is always given for Augustine, as Heidegger emphasizes; therefore, the genuine focus is on the enactment of them: How do we use our senses? How do we know? How do we live among our fellow humans? Do we enact them in search of God? Augustine's description of life as continual testing thus aims to awaken "a radical self-concern before God" (Heidegger 1995, 242; 2010b, 181). Heidegger's "before God" and Augustine's "before your eyes" open up the self to itself, not as certainty, but as question, concern, and distress.

\subsection{Saint Paul's Expectation of the Parousia}

In Grundprobleme der Phänomenologie, Heidegger cites Augustine's inquietum cor nostrum. ${ }^{6}$ Yet, the notion of restlessness and equivalents thereof, such as Unruhe, unruhig, and Beunruhigung, are hardly present in his lectures on Augustine. ${ }^{7}$ This is different in his lectures on Saint Paul: Unruhe, Beunruhigung and beunruhigen appear there more than 25 times. As in

5. I am not fully convinced by Coyne's (2011) argument that these three forms of defluction represent an intensification: they rather elaborate the phenomenon of the self-relation at stake in the searching for God. These forms of defluction seem to prefigure structures in Sein und Zeit: The forms of concupiscentia prefigure how our dealings with innerworldly beings can lead us away from our authentic potentiality-of-being, whereas the ambitio saeculi implies a similar risk in our mode of being-with others.

6. For my account of Heidegger's reading of Saint Paul, see also van der Heiden (2017, 2018).

7. There are some occurrences: Angst vor Unruhe (Heidegger 1995, 200), die Unruhe without further qualification $(1995,251)$; and one time: wahre Ruhe $(1995,296)$. 
his reading of Augustine and Descartes, Heidegger is concerned with the impact of Greek thought on Christianity and the way in which, in the course of the history of Christianity, the original Christian experience of life is articulated-or, rather, misarticulated in ancient philosophical forms of expression. Strictly speaking, however, Heidegger does not present us with a destruction of Paul's letters. Apparently, unlike Descartes' and Augustine's texts, these letters are not invested in the same way with the ancient Greek forms of expression. They offer a direct expression of the Christian experience of life, not mediated by ancient Greek conceptuality. Nevertheless, Heidegger's interpretation aims to offer an alternative to their historical reception, which did get overtaken by Greek forms of expression, hiding the original Christian formation of concepts and giving rise to a dogmatics that tends to amplify the objectifying tendencies of Greek thought and, correspondingly, hide the enactmental sense at stake in the apostle's letters (Heidegger 1995, 28, 39, 72, 97, 104; 2010b, 19, 27, 50-1, 67, 73). The claim that Paul's letters are not yet invested by Greek forms of expression, seems to be supported by Paul's objection to the "wisdom of the Greeks," which for Heidegger's Paul are part of the "falling tendency of life" (1995, 144; 2010b, 102; see also 1995, 116; 2010b, 83).

It is clear from the opening sections of the course that the motif of Beunruhigung concerns exactly this difference between the objectifying tendencies in philosophy and the focus on enactment that speaks from the Christian experience of life. ${ }^{8}$ Most of the references to Beunruhigung are found in $\S \S 7-10$, in which Heidegger discusses the sense of history that speaks from three different types of philosophy of history. These types, exemplified by the names of Plato, Spengler, and Dilthey, respectively, provide ways to free philosophy from "disturbance [Beunruhigung] of the historical" (1995, 39; 2010b, 27). Hence, these types are motivated by a similar care as the one motivating Descartes: a care aiming to move away from Beunruhigung, a care that sets our heart at rest; or in Heidegger's own terms: these philosophies are marked by a tendency-to-secure, Sicherungstendenz. Such a tendency is a response to the disturbance and distress caused by the historical. The question, however, is whether a philosophy that is marked by this tendency is capable of understanding this primal disturbance of human life as a historical, contingent life: "For us the question is whether these tendencies-to-secure correspond at all to the disturbing motive itself"

8. Note that the English translation renders Beunruhigung as "disturbance," but one might fear that this translation slightly fades or dulls the meaning of the German term. Beunruhigung is an intensified form of disturbance, namely alarm, anxiety, and distress. 
$(1995,47 ; 2010 \mathrm{~b}, 32)$. These philosophies aim to "defend themselves against history"; rather than aiming to interpret and face this disturbance philosophically, this disturbance is selbstverständlich-they take it for granted and do not investigate it. Therefore, Heidegger judges: "The theory of the science of history is an entirely secondary problem within the problem of the historical itself" (1995, 47; 2010b, 32).

Connecting the notions of Sicherung, Beunruhigung, and Bekümmerung and emphasizing the problematic role played by the objectifying tendency in these philosophies, Heidegger affirms this insufficiency of the philosophies of history: "Does the securing [Sicherung] suffice for that which drives forth the disturbance [Beunruhigung]? That which is disturbed [beunruhigt], the reality of life, the human existence in its concern about its own security [Bekümmerung um seine eigene Sicherung], is not taken in itself; rather it is regarded as object and as object it is placed within the historical objective reality" $(1995,51 ; 2010 \mathrm{~b}, 34)$. The philosophies of history do not examine history as it is lived; they objectify history and move away from history as a lived reality, thus losing the basic human historical concern about its own security, die Bekümmerung um seine eigene Sicherung. The letters of Paul, however, do not conceal this original concern but rather give a religious voice to it. Therefore, the Pauline articulation of the religious experience of life is a basic resource for a phenomenology that attempts to extricate itself from the ancient philosophical forms of expression and that aims to understand the meaning of the historical for human existence and the disturbance with which it is experienced.

In the previous section, I noted how, for Heidegger's Augustine, the question of self-experience and the discovery of the inner man is also the discovery of the question of how the self has God. Heidegger develops a similar line of inquiry in his reading of Paul. In the apostle's letters, the I's having of God cannot be understood in terms of Greek theōria or contemplation. In the original Christian experience, God is not the object of contemplation: "It is a decrease [Abfall] of authentic understanding if God is grasped primarily as an object of speculation"; we have not yet understood "because Greek philosophy penetrated into Christianity" (1995, 97; 2010b, 67). If the speculative, contemplative access to God is Greek-philosophical in nature and foreign to the original Christian experience of life, then how does the believer have God according to Paul? And what has this to do with the distressing experience of the historical?

In reference to 2 Cor. 12, Heidegger notes that, when describing this having, Paul actually excludes the particular "enrapturement" that happened to him on the road to Damascus: the genuine experience of being 
before God is neither the experience of an overflowing fulfilment with God nor is it the predecessor of the mystical experience based on a fruitio Dei. For the apostle, the genuine experience of being before God rather consists in weakness and distress. In the previous section, I noted that the Augustinian forms of defluction allow the bishop of Hippo to address the particular distress that marks a life that is experienced as a continual temptation and testing. In the apostle's proclamations, Heidegger discerns a predecessor of this analysis: Paul addresses the particular, intrinsic possibility of falling with the term sarx or flesh, which is "the original sphere of all affects not motivated from God" (1995, 98; 2010b, 69). Flesh is not the term to describe or assess the Christian experience of the body or of the bodily realm, but rather names a particular self-relation, namely the self-relation which consists in the self-loss that occurs when the self does not search for God.

The most significant phenomenon capturing the believer's relation to God in Paul's letters, however, is the Parousia, the return of the Lord, which according to Heidegger shows that "Christian experience lives time itself" (1995, 82; 2010b, 57) The Pauline believer has a specific experience of the Parousia (1 Thess., 2 Thess.), which exemplifies the religious experience of temporality and of the historical. ${ }^{10}$ Heidegger explicates this experience as the enactment of anticipation or waiting $(1995,97 ; 2010 \mathrm{~b}$, 67): believers anticipate the change that will come when the Lord returns, even though they do not know the exact time of his return. ${ }^{11}$ All the basic characteristics of the Pauline life experience are gathered in the following succinct and enigmatic way: "The experience is an absolute distress ... which belongs to the life of the Christian himself. The acceptance is an entering-oneself-into-anguish. This distress is a fundamental characteristic, it is an absolute concern in the horizon of the Parousia" (1995, 97-8; 2010b, 67). Why is this form of waiting "absolute distress" and "anguish"?

First, Heidegger emphasizes that the temporal experience at stake in the Parousia is marked by a fundamental uncertainty: no one knows when the Lord will return and when the present form of the world will pass. The time of the Parousia is not dateable: believers should not relate to it as an

9. The notion of parousia is a complicated one both in Greek language and in theology, with several different meanings and usages; note that Heidegger explains this briefly (1995, 102; 2010b, 71).

10. Another phenomenon that deserves to be discussed in this context is that of "having-become" (see Heiden 2018, 149-51).

11. Heidegger also emphasizes the role of doulein, to serve, which I have discussed in (van der Heiden 2018, 149-52). 
unknown point of time in the future, as Paul makes clear to those who try to compute the exact point in time of the Lord's return. Such an objective relation to the Parousia as a fixed moment in the future betrays its particular character in Christian life. Rather, as Paul claims, the Lord will return "like a thief in the night" (1 Thess. 5:2 NRSV). Hence, the return of the Lord and the accompanying overturning of the present form of this world are imminent in a particular way: they are possible, they can happen at each and every moment. That is, each and every moment of the believer's life ought to be oriented to this possibility of a radical ending and transformation of the world. Hence, to be before God means, in terms of this experience, that believers anticipate and await the actualization of this possibility at every moment in their lives. This is not an automatic anticipation but is rather a strenuous task: each moment needs to be lived in the expectation that the Lord may return this very moment. This is the feweiligkeit at stake in this awaiting and existing before God. The Parousia is not an objective occurrence in the order of linear time, but this phenomenon exists only in the enactment of the believer's expectation and awaiting of the Parousia as something that can happen at this very moment. This enactment presents itself as a strenuous task in each moment of the lives of believers. Therefore, Heidegger characterizes this experience as an experience of uncertainty and insecurity: "There is no security for Christian life; the constant insecurity is also characteristic for what is fundamentally significant in factical life" $(1995,105 ; 2010 b, 73)$. Believers can never say that they have achieved, once and for all, the anticipation of the Parousia. They may enact it now in their factical life, but there is no certainty that they will remain so.

All actions in factical life also need to be enacted in this mode of awaiting: nothing in the present form of the world is secure or certain. It is not a matter of doing different things, but of doing the same things differently, never in accordance with the present order of the world, which speaks of "peace and security" (Heidegger 1995, 103-4; 2010b, 72-3). All things must be enacted in the awareness that everything can all of a sudden be transformed. It is for this reason that Heidegger objects to Jaspers' suggestion that God is a "foothold [Halt]": this is "blasphemy!" (1995, 122; 2010b, 67) as Heidegger exclaims. The explication of God as a foothold falls back in the Greek account of God as eternal presence. God is not a foothold; God is rather a destabilizing force that lays bare and allows the human to experience the abyssal insecurity of human, historical life and that ignites the distress that goes hand in hand with it.

The expectation of a fundamental transformation of the world (1 Cor. 7:31) implies also that the Christian experience of this world is marked by 
a fundamental alienation from the world. In the Christian experience, the world is uncanny, unheimlich, because it is experienced as offering a false peace and security; believers are not at home in the world because they expect the return of the Lord and understand the present form of the world as one that is passing by. At the same time, Christian being-in-the-world is continuously exposed to the temptation to flee from this experience of uncertainty by familiarizing oneself with the world and the ways of the world, enjoying them, and living in the comfort of social appreciation by doing everything according to what is expected in the present order of the world. This risk of self-loss, inspiring Paul's appeal "not [to] be conformed to the world" (Rom. 12:2; Heidegger 1995, 120; 2010b, 85-6) marks the distress and anguish that recognizes life as a continual testing and uncertainty.

\section{Concluding Remarks: On Two Gods}

Looking back on the analysis that brought us from Descartes via Augustine to Paul, we conclude that Heidegger's fundamental distinction between philosophy's objectifying tendencies and phenomenology's task to think the enactment of life mirrors a double conception of God. Even though Christianity quickly and extensively incorporated ancient Greek forms of expression, there is a fundamental difference between Aristotle's God and Paul's God. Aristotle's God is the object of theoria and contemplation, and all beings long for it since it is the ultimate telos of all reality. This conception of God is therefore a blueprint for onto-theology. Especially when Greek thought and Christian ideas merge in the notion of a creator God, the onto-theological peak of history finds its way to modern thought, also motivating and influencing Husserl's phenomenology. Yet, at the same time, Heidegger discerns in phenomenology a radical attempt to extricate itself from these metaphysical and onto-theological structures of our conception of human life. In this sense, phenomenology aims at a radically different anthropology (Heidegger 1994, 279; 2005, 214). To achieve this end, however, phenomenology has to purify itself from the remainders of Greek thought and medieval onto-theology. If Heidegger's account of Husserl can also be characterized as a destruction, it is one that aims to retrieve a more undiluted version of itself to attain this particular aim. Heidegger's early readings of Augustine and Paul demonstrate that a phenomenology of religion is not a regional enterprise. Rather, for Heidegger, the Christian religion has an exemplary meaning since it attests to a unique experience of life, foreign to the Greek experiment of philosophy. This religious experience of living before God cannot be reduced to the contemplation of or speculation on the onto-theological God of Aristotle. Rather, in Augustine 
and Paul, the mode of living before God discloses in an exemplary way the human concern for their own being and paves the way to thinking the primacy of enactment in human life over objective content and relation.

This Christian religious experience is part and parcel of Western culture as much as Greek thought is. Therefore, it is a historical resource that Heidegger could tap into to recalibrate phenomenology as an attempt to think human existence. The importance of this resource is still emphasized by Heidegger in the 1950s, when he reflects: "Without this theological background I should never have come on the path of thinking" $(1985,91 ; 1971$, 10; Kisiel 1993, 80; Vedder 2006, 5) (1985, 91; 1971 10; see also: Kisiel 1993, 80; Vedder 2006, 5). In this sense, it seems impossible to conceive of Heidegger's ways of thinking without his early reflections on the Christian experience of life and his profound knowledge of Christian religion and Christian theology. Yet, Heidegger does not offer a Christian philosophy, but he does show how the formal retrieval of the Christian experience of life gives rise to a significant transformation of the phenomenological project allowing phenomenology to come into its own trajectory of thought, genuinely leading us beyond onto-theology. His retrieval of the Christian experience of life is exactly that: an attempt to arrive at a conception of human existence and the human self that no longer depends on the onto-theological structures undergirding the modern conception of the subject.

\section{BIBLIOGRAPHY}

Arendt, Hannah. 1978. The Life of the Mind. 2 vols. London: Harcourt.

Augustine. 2014. Confessions. Translated by Carolyn J.-B. Hammond. Vol. I. Books 1-8. Cambridge, MA: Harvard University Press.

- 2016. Confessions. Translated by Carolyn J.-B. Hammond. Vol. II. Books 9-13. Cambridge, MA: Harvard University Press.

Campbell, Scott M. 2012. The Early Heidegger's Philosophy of Life: Facticity, Being, and Language. New York: Fordham University Press.

Coyne, Ryan. 2011. "A Difficult Proximity: The Figure of Augustine in Heidegger's Path." The Journal of Religion 91 (3): 365-96. https://doi.org/10.1086/659749.

- 2015. Heidegger's confessions. The remains of Saint Augustine in Being and Time and beyond. Chicago: The University of Chicago Press.

Dahlstrom, Daniel. 2009. “Temptation, Self-Possession, and Resoluteness: Heidegger's Reading of Confessions X and What Is the Good of Being and Time." Research in Phenomenology 39 (2): 246-65. https://doi.org/10.1163/156916409X448193.

Grondin, Jean. 2012. Introduction to Metaphysics: From Parmenides to Levinas. Translated by Lukas Soderstrom. New York: Columbia University Press.

Heidegger, Martin. 1971. On the Way to Language. Translated by Peter D. Hertz. New York: Harper and Row.

- 1977. Sein und Zeit. Vol. GA 2. Frankfurt am Main: Vittorio Klostermann.

- 1985. Unterwegs zur Sprache. Vol. GA 12. Frankfurt am Main: Vittorio Klostermann. 
- 1993a. Grundprobleme der Phänomenologie (1919/20). Vol. GA 58. Frankfurt am Main: Vittorio Klostermann.

- 1993b. Phänomenologie der Anschauung und des Ausdrucks: Theorie der philosophischen Begriffsbildung. Vol. GA 59. Frankfurt am Main: Vittorio Klostermann.

- 1994. Einführung in die phänomenologische Forschung. Vol. GA 17. Frankfurt am Main: Vittorio Klostermann.

—. 1995. Phänomenologie des religiösen Lebens. Vol. GA 60. Frankfurt am Main: Vittorio Klostermann.

- 2005. Introduction to Phenomenological Research. Translated by Daniel O. Dahlstrom. Bloomington: Indiana University Press.

- 2010a. Phenomenology of Intuition and Expression: Theory of Philosophical Concept Formation. Translated by Tracy Colony. London: Bloomsbury.

- 2010b. The Phenomenology of Religious Life. Translated by Matthias Fritsch and Jennifer Anna Gosetti-Ferencei. Bloomington: Indiana University Press.

- 2012. Basic Problems of Phenomenology. Translated by Scott Campbell. London: Bloomsbury.

van der Heiden, Gert-Jan. 2014. Ontology after Ontotheology: Plurality, Event, and Contingency in Contemporary Philosophy. Pittsburgh, PA: Duquesne University Press.

- 2017. "The Experience of Contingency and the Attitude to Life: Nietzsche and Heidegger on Paul." In Rethinking Faith: Heidegger between Nietzsche and Wittgenstein, edited by Antonio Cimino and Gert-Jan van der Heiden, 166-77. London: Bloomsbury.

- 2018. Het uitschot en de geest: Paulus onder filosofen. Nijmegen: Vantilt.

van der Heiden, Gert-Jan van der, and George van Kooten. 2017. "Epilogue: Saint Paul and Philosophy-The Consonance of Ancient and Modern Thought." In Saint Paul and Philosophy: The Consonance of Ancient and Modern Thought, edited by Gert-Jan van der Heiden, George van Kooten and Antonio Cimino, 325-45. Berlin: De Gruyter.

Kisiel, Theodore. 1993. The Genesis of Heidegger's Being and Time. Berkeley: University of California Press.

Marion, Jean-Luc. 2004. Sur le prisme métaphysique de Descartes. 2 ed. Paris: Presses Universitaires de France.

Vedder, Ben. 2006. Heidegger's Philosophy of Religion: From God to the Gods. Pittsburgh, PA: Duquesne University Press. 